\title{
Calcinoid pus presenting as an abscess in a patient with limited cutaneous systemic sclerosis
}

\author{
Karthikeyan P Iyengar (D) , ${ }^{1}$ Muyed Kamal Awadalla Mohamed, ${ }^{1}$ Chetan Sangani, ${ }^{1}$ \\ Khushroo Suraliwala ${ }^{2}$
}

${ }^{1}$ Trauma \& Orthopaedics, Southport and Ormskirk Hospital NHS Trust, Southport, UK

${ }^{2}$ Orthopeadics, Southport and Ormskirk Hospital NHS Trust, Southport, UK

Correspondence to Karthikeyan P lyengar; kiyengar@nhs.net

Accepted 21 January 2021

\section{DESCRIPTION}

Systemic sclerosis $(\mathrm{SSc})$ is a rare autoimmune, connective tissue disorder of unknown aetiology. ${ }^{1}$ The prevalence of the disease is 19 cases in a million and it is more common in women aged $30-50$ years. SSc is characterised by widespread fibrosis of the skin, various internal organs or both of varying degree of severity. In limited cutaneous systemic sclerosis, previously called CREST Syndrome (calcinosis, Raynaud's phenomenon, oesophageal dysmotility, sclerodactyly, and telangiectasia syndrome), the skin tightening occurs distal to the elbows or knees and the face, while in diffuse SSc, the skin of the proximal extremities and trunk is involved. Current treatment for SSc is directed towards managing complications and providing symptomatic relief. In addition to disease-modifying treatments, surgical intervention may be required in infected lesions.

Calcinosis in SSc results from the deposition of insoluble calcium salts in the skin and subcutaneous tissues. Local trauma, vascular hypoxia and chronic inflammation leading to dysregulated mesenchymal stem cell differentiation and a bone-forming microenvironment have been

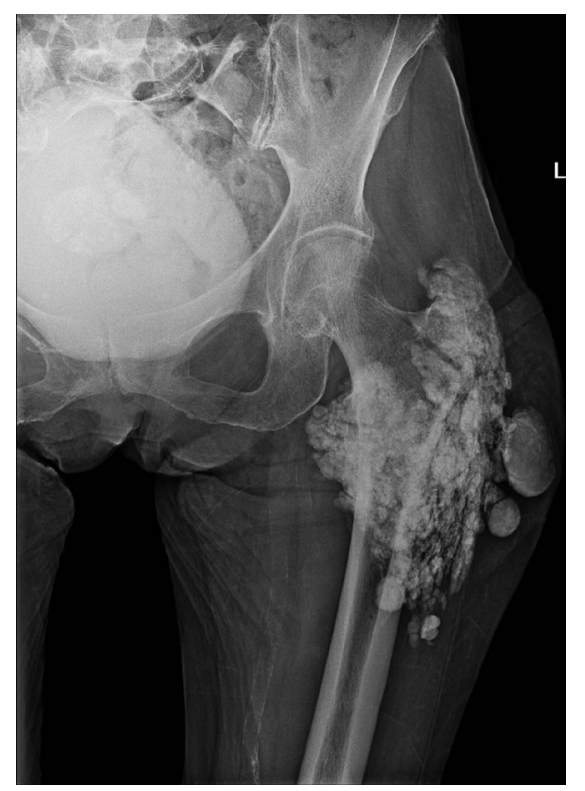

Figure 1 Plain radiograph of the left hip and thigh showing extensive, calcification centred over greater trochanter region extending into the surrounding soft tissue and no gross abnormalities in the underlying cortical bone.

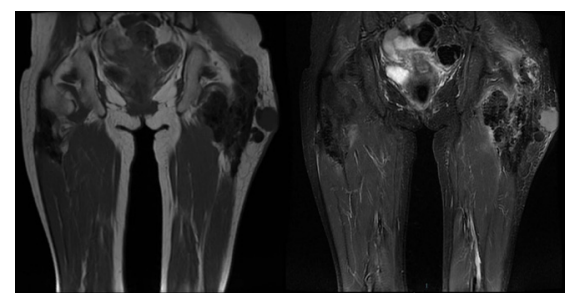

Figure 2 Contrast-enhanced MRI T1/T2 weighted of the pelvis showing a large fluid collection measuring $4.6 \times 3.6$ $\times 3 \mathrm{~cm}$, extending from the femur to the skin.

proposed to the formation of calcinosis. ${ }^{2}$ These heterotrophic ectopic calcific deposits may lead to ulceration, sinus formation and infection that contribute to SSc-associated morbidity. Clinical and radiological diagnostic imaging with surgical excision of symptomatic calcinoid deposits remain the mainstay of treatment. ${ }^{3}$

A 69-year-old woman with limited cutaneous SSc was referred to our orthopaedic unit with a 5 -month history of progressive dull aching pain and swelling in her left thigh. She was not on steroids or immunosuppression. Her current medication comprised vasodilators, antihypertensives and symptomatic treatment for dry eys and dry mouth. She was apyexial. Clinical examination demonstrated a large diffuse swelling in the left upper thigh with overlying erythema. It was tender to touch with pain-free ipsilateral hip joint movements. The plain radiographs revealed extensive calcific deposition centred over the region of the greater trochanter extending into the surrounding soft tissues; however, there was no gross abnormality in the underlying cortical bone (figure 1).

The blood markers showed a raised $\mathrm{C}$ reactive protein level of $70 \mathrm{mg} / \mathrm{L}$, a white cell count (WCC) of $8.5 \times 10^{9} / \mathrm{L}$ and an erythrocyte sedimentation rate of $78 \mathrm{~mm} /$ hours. T1 (precontrast and postcontrast) and T2 MRI revealed a large fluid collection measuring $4.6 \times 3.6 \times 3 \mathrm{~cm}$, all the way down, lateral and posterior to the proximal femur with a rim enhancement (figure 2). On the suspicion that this was an abscess, the patient was taken to theatre for incision and drainage.

Surgical exploration revealed a large collection of dense white fluid (figure 3). Microbiological examination showed high leucocytes but no microorganisms. Extended cultures were negative. The presence of carbonated hydroxyapatite crystals confirmed the diagnosis of liquefied 


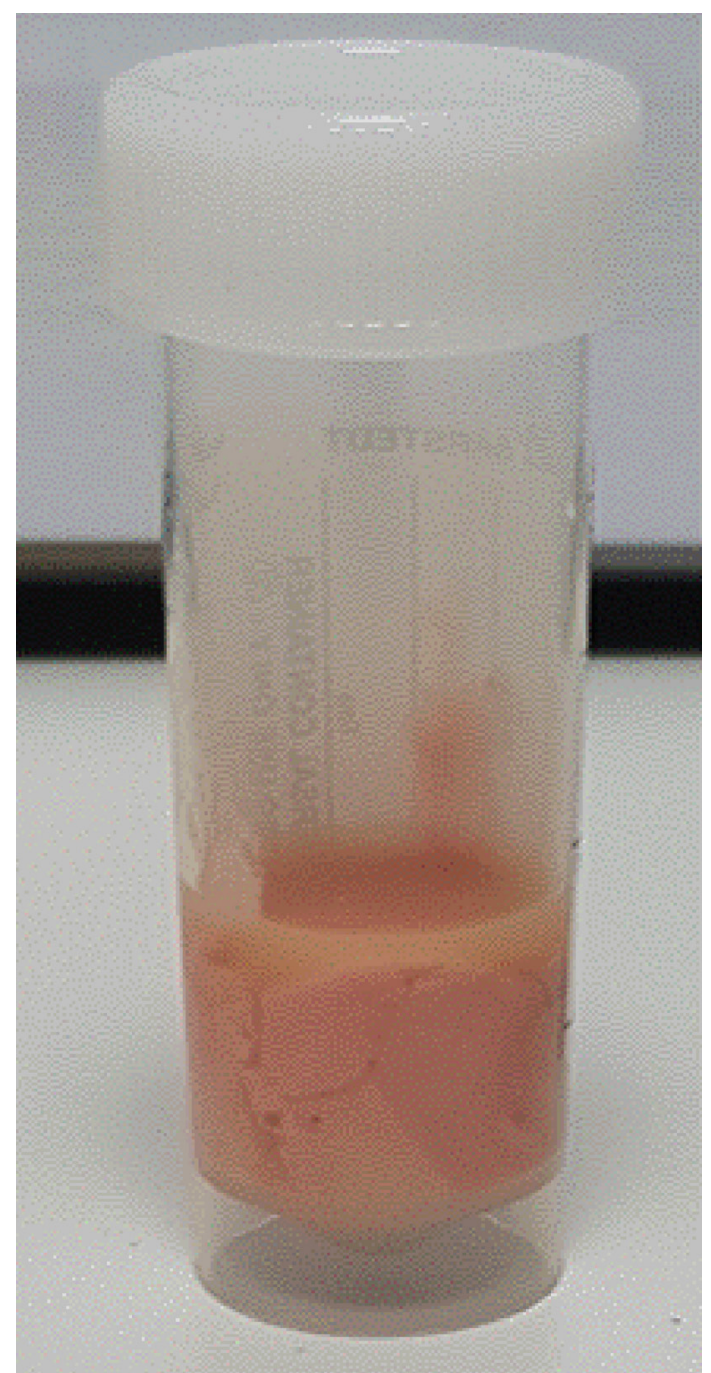

Figure 3 Specimen pot with fluid collected on surgical exploration and sent for microbiological examination. calcific pus. The wound healed with secondary intention, over a period of several weeks, leaving behind a puckered scar. The patient felt significant symptomatic relief.

This case highlights the clinical manifestation of a rare disorder. An inflammatory collection of calcinoid pus can present as an abscess. Familiarity with radiological features and complementary imaging helps determine the extent and localisation of the problem. Surgical treatment provides microbiological confirmation and resolution of symptoms.

\section{Learning points}

- Calcinosis in systemic sclerosis (SSc) can mimic an infective process or a tumour.

- Calcinosis in SSc is a common cause of morbidity and can be found incidentally on radiographs or seen as obvious clinical presentation.

- Surgical exploration helps in microbiological diagnosis and definitive management of unusual liquefied calcinoid collection

Contributors KPI: conceptualisation, literature search, manuscript writing and editing. MKAM and CS: literature search, manuscript writing, references and editing. KS: supplemented literature search, edited manuscript, supervised and approved final draft.

Funding The authors have not declared a specific grant for this research from any funding agency in the public, commercial or not-for-profit sectors.

Competing interests None declared.

Patient consent for publication Obtained.

Provenance and peer review Not commissioned; externally peer reviewed.

\section{ORCID iD}

Karthikeyan P lyengar http://orcid.org/0000-0002-4379-1266

\section{REFERENCES}

1 Barsotti S, Orlandi M, Codullo V. One year in review 2019: systemic sclerosis. Clin Exp Rheumatol 2019:119:3-14.

2 Hsu V, Varga J, Schlesinger N. Calcinosis in scleroderma made crystal clear. Curr Opin Rheumatol 2019:31:589-94.

3 Valenzuela A, Chung L. Calcinosis: pathophysiology and management. Curr Opin Rheumatol 2015:27:542-8

Copyright 2021 BMJ Publishing Group. All rights reserved. For permission to reuse any of this content visit

https://www.bmj.com/company/products-services/rights-and-licensing/permissions/

BMJ Case Report Fellows may re-use this article for personal use and teaching without any further permission.

Become a Fellow of BMJ Case Reports today and you can:

- Submit as many cases as you like

- Enjoy fast sympathetic peer review and rapid publication of accepted articles

- Access all the published articles

- Re-use any of the published material for personal use and teaching without further permission

\section{Customer Service}

If you have any further queries about your subscription, please contact our customer services team on +44 (0) 2071111105 or via email at support@bmj.com.

Visit casereports.bmj.com for more articles like this and to become a Fellow 